\title{
MORAL PESERTA DIDIK DAN PENDIDIKAN ISLAM MENURUT PEMIKIRAN ‘ATHIYAH AL-ABRASHYI
}

\author{
Fikri Abdul Aziz \\ Universitas Islam Negeri Sunan Kalijaga Yogyakarta, Indonesia \\ 12aziz93@gmail.com
}

DOI: 10.20885/tarbawi.vol13.iss1.art3

\begin{abstract}
Basically, the real purpose of Islamic education is to produce moral students. The problem is that in Islamic Education there are still many moral deviations committed by people of various backgrounds and ages in Indonesia. Islamic education has not fully led to moral education. The purpose of this study was to determine the biography and thoughts of 'Athiyah al-Abrashyi in education, and the concept of moral education for students. This research method is library research. The results of this study indicate that the educational basis of 'Athiyah Al-Abrasyi brings the concept of a learning process that leads students to become adult humans. To achieve the true goal of Islamic education, 'Athiyah al-Abrashyi offers a concept of educational thought that can be used as a reference for education in Indonesia today.
\end{abstract}

Keywords: islamic education; thougth; moral education; students;

\begin{abstract}
Abstrak
Pada dasarnya tujuan pendidikan Islam yang sebenarnya adalah mencetak siswa yang bermoral. Persoalannya, bahwa Pendidikan Islam masih banyak terjadi penyimpangan moral yang dilakukan oleh masyarakat dari berbagai kalangan dan usia di Indonesia. Pendidikan Islam belum sepenuhnya mengarah ke pendidikan moral. Tujuan dari penelitian ini adalah untuk mengetahui biografi dan pemikiran 'Athiyah al-Abrashyi dalam pendidikan, dan konsep pendidikan
\end{abstract}




\section{el-Tarbawj Fikri Abdul Aziz}

moral bagi siswa. Metode penelitian ini adalah penelitian kepustakaan. Hasil penelitian ini bahwa dasar pendidikan pemikiran 'Athiyah Al-Abrasyi membawa konsep tentang proses pembelajaran yang mengarahkan pada peserta didik menjadi manusia dewasa. Untuk mencapai tujuan pendidikan Islam yang sebenarnya, 'Athiyah al-Abrashyi menawarkan konsep pemikiran pendidikan yang dapat dijadikan acuan pendidikan di Indonesia saat ini.

Kata Kunci: Pendidikan Islam; Pemikiran; Pendidikan Moral; Peserta Didik;

\section{Pendahuluan}

Agama Islam merupakan agama ilmu pengetahuan dan cahaya. Agama Islam menuntun manusia dalam menjalani kehidupan melalui pengetahuan yang tertulis dalam kitab suci dan yang disampaikan oleh para rasulnya. Oleh karna itu, agama seseorang dianggap tidak sempurna apabila ia hidup dalam kebodohan dan kegelapan. Ayat alQur'an yang pertama diturunkankan memiliki aspek yang sangat transparan dalam pemahaman pendidikan, yaitu perintah membaca bagi Rasulullah. Perintah tersebut dilakukan secara berulang-ulang dengan menyebutkan bentuk pengajaran yang disandarkan pada Allah Swt. Menurut Prof. Dr. Azyumardy Azra, dunia pendidikan Islam memiliki karakteristik yaitu penguasaan ilmu pengetahuan. Ajaran dasar Islam mewajibkan mencari ilmu pengetahuan bagi setiap muslim dan muslimat. Mereka diperintahkan untuk mengembangkan ilmu pengetahuan agar mendapatkan penghormatan sebagai makhluk Tuhan. Penghormatan tersebut didasarkan atas pengakuan potensi dan kemampuan seseorang untuk berkembang dalam suatu kepribadian.

Pendidikan Islam tidak hanya dikembangkan sebagai pengetahuan kognitif, namun lebih pada bagaimana mencetak akhlak yang sempurna. Tujuan dasar penyempurnaan akhlak tersebut sejalan dengan tujuan Allah menugaskan Nabi Muhammad untuk 
menyempurnakan akhlak. Para ahli pendidikan Islam telah sepakat bahwa maksud dari pendidikan dan pengajaran bukanlah memenuhi pengetahuan peserta didik dengan segala macam ilmu yang belum mereka ketahui. Tetapi lebih pada mendidik akhlak dan jiwa, menanamkan rasa fadhilah (keutamaan), membiasakan dengan kesopanan yang tinggi, dan mempersiapkan peserta didik untuk suatu kehidupan yang suci. Pendidikan moral sebagai salah satu bagian dalam pendidikan akhlak dalam Islam, menjadi kajian yang penting dari masa ke masa. Semakin berkembangnya zaman maka akan semakin kompleks pula permasalahan moral yang ada. Oleh karenanya, Islam memandang pendidikan sebagai modal utama dalam kehidupan manusia. Melalui pendidikan nilai-nilai dalam ajaran Islam yang menyangkut tentang moral akan tersampaikan pada peserta didik.

Implementasi pendidikan moral di Indonesia secara eksplisit diatur dalam peraturan perundang-undangan. Undang-Undang Nomor 20 tahun 2003 tentang Sistem Pendidikan Nasional pada Pasal 3 menyebutkan bahwa tujuan pendidikan nasional adalah "mengembangkan potensi peserta didik agar menjadi manusia yang beriman dan bertakwa kepada Tuhan Yang Maha Esa, berakhlak mulia, sehat, berilmu, cakap, kreatif, mandiri, dan menjadi warga negara yang demokratis serta bertanggung jawab". Hal tersebut berimplikasi pada bagaimana cara guru dan orang tua dalam menyikapi dan menyampaikan nilai-nilai agama agar tertanam dalam diri peserta didik menjadi salah satu tujuan pendidikan itu sendiri.

Namun pada kenyataannya, di Indonesia masih banyak terjadi penyimpangan moral yang dilakukan oleh masyarakat dari berbagai kalangan dan usia. Terlebih ketika memasuki era distruptif yang membuat kondisi masyarakat dalam berbagai aspek kehidupan menjadi tidak dapat diprediksi. Berdasarkan hal tersebut perlu adanya konsep pendidikan moral yang relevan dengan perkembangan zaman sehingga lebih mudah diaplikasikan. Penelitian ini mencoba 


\section{el-Tarbawj Fikri Abdul Aziz}

membahas konsep pendidikan sesuai dengan pemikiran salah satu ilmuwan muslim yaitu 'Athiyah al-Abrashyi. Pada masa pemerintahan Abd. Naser di Mesir tahun 1954-1970 seorang tokoh pendidikan yaitu Muhammad Athiyah al-Abrasyi. Beliau adalah salahsatu cendekiawan Arab dan muslim yang mendalami ilmu tentang pendidikan Keislaman. Pemikiran beliau relevan bila diaplikasikan dalam pendidikan di Indonesia karena sesuai dengan kebutuhan era sekarang. Bahkan di beberapa sekolah unggulan di Indonesia mengusung model pendidikan sesuai dengan konsep atau pemikiran beliau.

\section{Metode Penelitian}

Metode penelitian yang digunakan adalah kepustakaan. Penelitian kepustakaan merupakan penelitian yang dikumpulkan dari data-data library, misalnya buku-buku, ensiklopedia, jurnal-jurnal ilmiah, koran, majalah, dan dokumen-dokumen (Syaodih, 2009). Pada hal ini, peneliti mencoba mencari data, menganalisis data, dan menelaah kejadian-kejadian yang sekarang ini terjadi yaitu pendidikan moral pada peserta didik dengan sudut pandang pemikiran Muhammad Athiyah al-Abrasyi.

Penelitian ini bukan pengamatan langsung melainkan penggunaan data sekunder yang didapatkan. Kajian pendidikan moral dan pemikiran Muhammad Athiyah al-Abrasyi dikumpulkan dari data-data dan buku. Data yang dikumpulkan bersumber dari buku, media cetak, jurnal dan lain-lain. Pada penelitian ini menggunakan dokumentasi juga untuk memperoleh data-data pendukung demi lancarnya perolehan data. Analisis data, reduksi data dan perapihan data dalam hasil analisis. Tahap selanjutnya penampilan pemikiran Muhammad Athiyah al-Abrasyi terkait pendidikan moral bagi peserta didik. Kemudian diverifikasi dengan tahap tambahan data pendukung lainnya. 


\section{Hasil Penelitian Dan Pembahasan}

Muhammad Athiyah al-Abrasyi merupakan sarjana yang sudah bergabung dalam dunia Pendidikan di Mesir, beliau juga seorang guru besar guru besar di Darul Ulum Kairo University (Al-Abrasyi, 1970). Beliau lahir tahun 1897 dan meninggal 17 Juli 1981. Menurut Abu Zahrah bahwa "Ia telah menghabiskan hampir seluruh umurnya untuk menuntut ilmu, semenjak mempelajari tentang keIslaman pada tingkat Madrasah, sampai ke Dar al-Ulum di mesir, dan kemudian dilanjutkan ke Inggris untuk mendalami ilmu jiwa dan pendidikan". Pernyataan tersebut menggambarkan bahwa sosok Muhammad Athiyah al-Abrasyi merupakan ilmuwan muslim yang mumpuni. Pemikiran-pemikirannya banyak dijadikan dasar dalam pengembangan ilmu pengetahuan, khususnya dalam pendidikan akhlak dan moral. Pembahasan pada penelitian ini khusus mengkaji tentang pemikiran Muhammad Athiyah al-Abrasyi terkait pendidikan moral bagi para peserta didik. Pemikiran tersebut menjadi dasar dalam merumuskan berbagai komponen pendidikan, diantaranya adalah:

\section{Konsep Pendidikan}

Jika kita menginginkan kehidupan yang wajar maka pendidikan merupakan suatu keharusan. Manusia hidup lebih sempurna dikarenakan pendidikannya, menjadi bahagia, cinta terhadap tanah airnya, sehat jasmaninya, akhlaknya baik, fikirannya sistematis, perasaannya halus, pintar bekerja, dan baik tulisannya (Anas Adi, 2018). Pendidikan dapat menjadikan manusia memiliki derajat yang berbeda dengan makhluk lain yang Allah ciptakan di semesta alam ini.

Pendidikan secara umum pada dasarnya merupakan kebutuhan yang primer manusia yang mengarah kepada terbentuknya kepribadian yang utama. Secara individu ataupun dalam masyarakat, pendidikan Islam merupakan menjadi landasan yang relevan dan 


\section{el-Tarbawj Fikri Abdul Aziz}

mampu menampakan diri sebagai kekuatan kultur Islam yang proposional, sesuai dengan naturnya, dan sesuai dengan al-Qur'an yang memerlukan sikap ilmiah(Al-Abrasyi, 1970).

Sangat familiar sekali bahwa yang digunakan untuk istilah Pendidikan islam adalah tarbiyah, ta'lim, dan $t a^{\prime} d i b$. Jika Pendidikan Islam menurut 'Athiyah al-Abrasyi dalam kitab at-Tarbiyah al-islamiyah Wafalasifatuha adalah:

Sesungguhnya pendidikan Islam itu meliputi prinsip-prinsip (demokrasi), yaitu kebebasan, persamaan, dan kesempatan yang sama dalam pembelajaranya, dan untuk memperolehnya tidak ada perbedaan antara si kaya dan simiskin, sesungguhnya mencari ilmu bagi mereka merupakan suatu kewajiban dalam bentuk inmateri, bukan untuk tujuan materi (kehendak), dan menerima ilmu itu dengan sepenuhnya hati dan akal mereka, dan mereka banyak melaksanakan perjalanan panjang dan sulit dalam rangka memecahkan masalah-masalah agama.('Athiyah alAbrasyi, 1975)

Sudah jelas bahwa konsep pendidikan yang digagas oleh 'Athiyah al-Abrasyi merupakan pendidikan yang mengutamakan Hak Asasi Manusia. Pendidikan tersebut memiliki prinsip kebebasan, persamaan, dan kesempatan yang sama dalam pembelajaran. Untuk memperolehnya tidak membedakan status seseorang yang menjadi dasar dalam kehidupan umat manusia. Mencari ilmu dipandang suatu kebaikan bagi setiap individu yang tercipta dari dalam hati bukan melalui nafsu belaka.

Pernyataan yang disampaikan oleh 'Athiyah tersebut menunjukan bahwa pendidikan merupakan sesuatu yang dibutuhkan dalam suatu masyarakat secara menyeluruh. Pendidikan menurut 'Athiyah memang ideal untuk diterapkan di dalam dunia pendidikan secara umum. Hal itu dapat dilihat dari dimensi kependidikan, baik bentuk orientasi, sikap, maupun volume yang selalu dipengaruhi oleh pengaruh internal maupun eksternal dari diri manusia. Tujuannya 
adalah agar ada perubahan pandangan, pikiran, dan tindakan terutama adanya kesiambangan dari berbagai disiplin ilmu.dalam menghadapi kemajuan zaman dan tantangannya(Djuwaeli, 1998).

\section{Dasar Pendidikan Moral}

Hal yang menjadi dasar dalam pendidikan menurut 'Athiyah adalah Pendidikan Islam. Dasar-dasar kuat dan relevan dalam kehidupan itu merupakan hasil buah dari Pendidikan untuk memenuhi segala kebutuhan masyarakat (Anas Adi, 2018).

Beberapa dasar pendidikan pemikiran 'Athiyah Al-Abrasyi pada dasarnya membawa konsep yang menyatakan bahwa proses pembelajaran merupakan upaya mengarahkan peserta didik sebagai manusia yang belum dewasa. Dalam Islam peserta didik adalah manusia yang memiliki fitrah yang membutuhkan pengajaran, pelatihan, dan bimbingan dari pendidik. Tujuannya adalah untuk mengantarkan kepada pematangan diri. Fitrah yang dimiliki jika ditangani dengan baik akan membawa peserta didik akan menjadi seorang yang bertauhid kepada Allah dengan potensi keilmuan yang dimilikinya (Rasyidin, 2012).

'Athiyah Al-Abrasyi menyebutkan bahwa ada beberapa dasardasar pokok pendidikan Islam diantaranya yaitu:

Pertama, Tidak ada pembatasan umur untuk mulai belajar. Hal ini berarti kesempatan dalam memperoleh pendidikan dapat berlangsung dimana saja, kapan saja, dan tidak ada pembatasan usia terhadap peserta didik yang ingin mendapatkan ilmu. Pendidikan pada dasarnya harus menyesuaikan dengan keadaan dan psikologi seorang anak yang beragam. Hal tersebut dikarenakan setiap individu memiliki kemampuan dan karakter yang berbeda-beda, sehingga pendidikan harus selalu dinamis. Terlebih pada pendidikan dasar, sifatnya bukan hanya konseptual tetapi juga teknis.

Periodisasi masa perkembangan kehidupan seorang peserta didik pada umumnya adalah sebagai berikut: usia 0-2 tahun 


\section{el-Tarbawj Fikri Abdul Aziz}

merupakan masa vital yaitu masa awal kehidupan yang menjadi dasar penting bagi kehidupan jasmani dan rohani anak. Pada masa ini orang tua punya andil yang besar untuk melatih kehidupan secara teratur; usia 2-7 tahun masuk ke masa estetis yaitu masa anak-anak mengalami perkembangan panca indera (peka). Masa ini sering ditandai dengan munculnya kenakalan dan pengalaman bahasa mengalami kemajuan pesat; usia 7-13 tahun adalah masa intelektual; sedangkan usia 13-21 tahun merupakan masa sosial/remaja (Mustaqim, 2001).

Kedua, Tidak ada batasan lamanya anak belajar di sekolah. Hal tersebut 'Athiyah tegaskan dengan mengatakan " tidak ada batasan usia lamanya anak dalam belajar disekolah-sekolah, maka anak-anak itu dikirim ketempat-tempat belajar untuk belajar membaca dan menulis, kemudian dilanjutkan dengan hafalan surat-surat pendek dari al-Qur'an". Sekolah merupakan rumah kedua bagi peserta didik untuk tumbuh dan mengembangkan potensi, sehingga bisa menjadi manusia yang bermanfaat bagi masyarakat, negara dan agama. Sistem pembelajaran yang menjadi pokok pemikiran 'Athiyah yang terdapat di Indonesia adalah sistem full day school. Sistem tersebut melaksanakan pembelajaran sehari penuh dengan mengemas seluruh program pembelajaran dan kegiatan peserta didik dalam sebuah sistem pendidikan yang bernuansa islam(Arifin, 2012).

Ketiga, berbedanya cara yang digunakan dalam memberikan pelajaran. Maksudnya, bahwa metode yang digunakan harus disesuaikan dengan situasi dan kondisi peserta didik dalam proses pembelajaran. Dalam pembelajaran, jika metode yang digunakan monoton maka peserta didik akan cepat bosan dan jenuh. Agar hal itu tidak terjadi, seorang guru harus memiliki metode yang bervariasi dalam menyampaikan materi. Pada dasarnya variasi dalam pembelajaran adalah perubahan dalam proses kegiatan yang bertujuan untuk meningkatkan motivasi belajar peserta didik, serta mengurasi kejenuhan dan kebosanan peserta didik. 
Keempat, Dua ilmu jangan dicampuradukan. Artinya seorang pendidik tidak diperkenankan dalam mengajarkan dua ilmu sekaligus. Pada dasarnya setiap individu ataupun seorang pendidik yang telah melalui berbagai proses pendidikan yang ditempuh akan memiliki satu keahlian. Hal itu mempengaruhi pandangan pendidik ketika mengajar pada satu pembelajaran bisa terfokus pada siapa dan apa yang diajarkan.

Kelima, Menggunakan contoh-contoh yang dapat dicapai dengan panca indera untuk mendekatkan pengertian pada anak-anak. Pada praktek pendidikan saat ini, seorang pendidik harus pandai memanfaatkan media pembelajaran yang mendukung dalam perkembangan anak melalui panca indera agar anak dengan mudah memahami apa yang ingin disampaikan oleh pendidik tersebut.

Keenam, Memperhatikan pembawaan anak dalam beberapa mata pelajaran sehingga mereka dengan mudah dapat mengerti. Dalam hal ini peran seorang pendidik adalah melihat potensi masing-masing peserta didik. Potensi tersebut dikembangkan dan diasah sebaik mungkin sehingga menjadikan peserta didik memiliki keahlian dibidangnya.

Ketujuh, Memulai dengan pelajaran bahasa arab kemudian pelajaran al-Qur'an. Pada keadaan ideal dalam mendidik anak dalam Islam pada dasarnya mengutamakan pengajaran bahasa arab. Ketika seorang anak tidak asing dengan bahasa arab, maka untuk mempelajari al-Qur'an akan lebih mudah. Ada satu pepatah mengatakan "belajar diwaktu kecil bagai mengukir diatas batu dan belajar diwaktu besar bagai mengukir di dalam air". Pepatah tersebut memiliki arti untuk memperkenalkan peserta didik pada al-Qur'an, peserta didik harus dikenalkan sejak dini tentang bahasa arab agar lebih mengenal dan membekas dalam diri, sehingga waktu besar tidak asing dengan pembelajaran Al Qur'an.

Kedelapan, Pengertian terhadap pembawaan insting anak-anak dalam pemilihan pekerjaan. 'Athiyah berkata "sungguh para sarjana- 


\section{el-Tarbawj Fikri Abdul Aziz}

sarjana pendidikan Islam khususnya Ibnu Sina menganjurkan untuk memperhatikan kecenderungan dan kesiapan (potensi dan tabiat) peserta didik ketika menunjukan bidang pekerjaan yang akan dipilih untuk masa depan hidupnya". Kekhasan potensi diri dari setiap peserta didik berpengaruh besar terhadap pembentukan pemahaman diri dan konsep diri, hal ini juga berpengaruh terhadap cita-cita dan prestasi yang hendak diraih didalam kehidupannya kelak. Salah satu peran agar potensi siswa berkembang.

Kesembilan, Permainan dan hiburan, dalam kitab At-Tarbiyah AlIslamiyah wa Falsafatuha 'Athiyah menyebutkan bahwa "sesungguhnya anak-anak itu membutuhkan kesempatan untuk bermain dan beristirahat setelah selesai pelajaran. Pendidikan yang baik adalah pada saat titik jenuh dalam pembelajaran, seorang pendidik memberi kesempatan kepada peserta didik melakukan aktivitas permainan dan hiburan. Karena dengan permainan dan hiburan dapat mengeluarkan ekspresi jiwa maupun potensi-potensi yang terpendam dalam diri peserta didik, serta mendapatkan kepuasan dan kesehatan maksimal.

Kesepuluh, Mendidik perasaan. Pemikiran adalah hasil dari perasaan dan perasaan adalah induk dari pemikiran. Dalam keadaan ideal, pendidikan perasaan yang ada di sekolah pada dasarnya untuk menumbuhkan rasa kagum terhadap keagungan dan kebesaran Allah dari pembelajaran yang didapat dari para pendidik yang mengajarkan berbagai disiplin ilmu.

\section{Kedudukan Guru}

Guru merupakan motor dari suatu pendidikan yang ada dalam suatu instansi. Guru mengemban tugas mulia, yaitu mendidik dan membina para peserta didik untuk menjadi anak-anak yang pandai, bermoral tinggi, dan berakhlak mulia (Sujarwo, 2010). Sehingga tugas seorang guru tidak hanya mentrasfer ilmu untuk menjadikan anak didiknya hafal dan mengerti materi pelajaran yang diberikan. Namun 
seorang guru juga harus mampu mentransfer nilai untuk menjadikan anak didik sebagai insan yang mulia dan memiliki moral yang baik.

Menurut 'Athiyah al-Abrasyi guru merupakan bapak "Spiritual" atau pemberi semangat bagi murid. Segala ilmu, bimbingan dan pelurusan akhlak sebenarnya bersumber dari guru untuk para murid-muridnya. Artinya timbal balik yang diberikan dari masyarakat kepada para guru akan memberikan hal baik pula yang diberikan guru kepada muridnya dengan cara benar-benar melaksanakan tugasnya secara baik ('Athiyah Al-Abrasyi, 1996).

Guru dan murid sesungguhnya dua teman dalam kebaikan, tidak ada lebih baik dari keduanya. Seorang guru memanfaatkan waktu dengan penuh perhatian dan melaksanakan tugas dengan penuh keagungan. Guru memiliki kedudukan yang sangat tinggi, kemerdekaan atau kebebasan yang mutlak dalam mengajar, memilih materi dan waktu mengajar serta jumlah materi yang akan disampaikan dalam pengajaran ('Athiyah Al-Abrasyi, 1996).

Dari pernyataan tersebut dapat kita artikan bahwa seorang guru tidak terpaku dengan hanya menyampaikan materi secara tekstual. Guru benar-benar harus memiliki keahlian dalam memberikan suatu materi. Secara tidak langsung guru harus memiliki ilmu yang memadai sehingga guru bisa mengintegrasikan berbagai ilmu dan sistem nilai dengan ke agungan Allah dan ke Esa-an Allah Swt. Melalui hal tersebut guru dapat menunjukan ibroh (pelajaran berharga), sehingga dapat menghasilkan peserta didik yang bukan hanya pandai, namun juga yang benar-benar mengenal Tuhannya dan memilik akhlak yang mulia (Sujarwo, 2010).

Menurut Athiyah Al-Abrasyi sifat-sifat yang harus dimiliki guru dalam mendidik moral peserta didik adalah ('Athiyah Al-Abrasyi, 1996); 1) memiliki sifat zuhud dan mengajar karena mencari ridha Allah; 2) suci dan bersih; 3) memiliki rasa ikhlas dalam melaksanakan tugas; 4) bersikap murah hati; 5) tegas dan terhormat; 6) memiliki 


\section{el-Tarbawj Fikri Abdul Aziz}

sikap kebapakan atau keibuan sebelum menjadi guru; 7) memahami karakteristik murid; 8) menguasai materi pelajaran.

\section{Konsep Peserta Didik}

Pendidikan pada dasarnya pencarian kognitif, afektif, dan psikomotorik yang tidak disadari oleh semua orang peserta didik untuk didapatkan. Belajar untuk mengembangkan dirinya melalui Pendidikan tersebut. Suatu hal yang harus disadari sebagai pendidik, menempatkan oranglain sebagi orang yang paling agung dalam menjunjung kehendaknya mencari ilmu pengetahuan.

Pendidikan Islam dipandang ada kewajiban dan ada hak pada peserta didik, termasuk para peserta didik yang diajarkan akhlak mulia harus menjadi pedomannya. Adapun etika yang menjadi pedoman peserta didik antara lain yaitu (Sujarwo, 2010):

Pertama, peserta didik ingin menambah keilmuannya dengan kutamaan mencari dan mendekatkan dirinya kepada Allah Swt, bukan bermaksud untuk menampakkan diri ingin dilihat orang lain, berbangga dan gagah terhadap ilmunya. Berdasarkan pernyataan tersebut terdapat ungkapan peserta didik mengisi jiwanya dengan fadhilah, dan mendekatkan diri kepada Allah menunjukan bahwa seorang peserta didik harus ikhlas dalam mencari ilmu hanya untuk mendapatkan ridho dari Allah. Ketika di dalam diri peserta didik tertanam nilai keikhlasan dalam menuntut ilmu, peserta didik akan dengan mudah menerima ilmu-ilmu yang diajarkan oleh pendidik sehingga prestasi akan mudah didapatkan.

Kedua, bersedia mencari ilmu walaupun harus meningggalkan tanah kelahiran dan keluarga yang dicintainya dengan tidak adanya suatu keraguan didalam hati demi mendapatkan guru agar meningkatkan kualitas keilmuan. Guna mencari tempat terbaik sesuai dengan potensi anak agar berkembang dengan baik, maka orang tua harus jeli dalam memilih tempat pendidikan walaupun jauh dari tempat tinggal. Bahkan bisa jadi jika hal itu bisa memisahkan antara 
orang tua dan anak, misalnya anak memiliki potensi dalam hal agama maka orang tua yang baik adalah orang tua yang mau merelakan anak untuk menuntut ilmu ke pondok pesantren dengan harapan potensi anak bisa berkembang dengan baik.

Keempat, hendaklah istiqomah terhadap salah seorang guru sebelum kita benar-benar menguasai apa yang diajarkannya. Dalam hal ini tidak bisa seorang peserta didik dengan mudah ingin menggantikan guru yang mengajarkannya karena pada dasarnya dalam sistem pendidikan terutama pendidikan dasar guru ditiap-tiap tingkatan dan bidang telah disesuaikan dengan keahliannya masingmasing.

Kelima, hendaklah seorang guru dihormati dan dimuliakan serta mengagungkannya karena Allah, dan berusaha menyenangkan hati guru dengan cara yang baik, karena guru merupakan sumber ilmu yang akan mentrasfer ilmu kepada peserta didik. Guru memiliki tugas yang tidak ringan. Guru bukan hanya sebagai tenaga pengajar tetapi juga sekaligus sebagai pendidik. Dengan kedudukan sebagai pendidik, guru berkewajiban untuk mewujudkan tujuan pendidikan islam termasuk pendidikan moral. Sehingga kedudukan seorang guru atau pendidik sangatlah istimewa (Langgulung, 1991).

Keenam, ketika peserta didik bertanya, maka berilah pertanyaan yang sesuai kapasitas seorang guru sehingga menghidari guru menjadi kerepotan dengan pertanyaan yang tidak sesuai dengan kapasitasnya. Peserta didik juga harus memiliki sopan santun saat berjalan dihadapat guru, jangan duduk ditempat duduknya, dan jangan memulai bicara kecuali setelah mendapatkan izin darinya.

Ketujuh, jangan membukakan rahasia kepada guru, jangan menipu guru, jangan minta guru membukakan rahasia, dan diterima pernyataan maaf dari guru bila saat seorang guru melakukan sebuah kesalahan dalam berbicara atau menyampaikan segala sesuatu. Pada dasarnya seorang guru juga merupakan manusia biasa, namun 


\section{el-Tarbawj Fikri Abdul Aziz}

memiliki tugas yang berat dalam menumbuh kembangkan potensi seorang peserta didik agar memiliki karakter yang bermoral.

Kedelapan, bersungguh-sungguh dan tekun belajar, bertanggung jawab siang malam untuk memperoleh pengetahuan dengan terlebih dahulu mencari ilmu yang lebih penting. Dalam meraih sebuah kesuksesan, jika tidak dibarengi dengan kesungguhan hati dan fokus maka akan menemui kegagalan.

Kesembilan, didalam diri seorang peserta didik harus memiliki rasa saling mencintai dan persaudaraan sehingga dalam pergaulan antar peserta didik seperti suatu keluarga yang hidup rukun dan saling menghargai. Pendidikan pada saat ini mengedepankan pendidikan karakter yang saling menghargai, yaitu dengan menerima segala sesuatu perbedaan didalam kehidupan dengan memperlakukan orang lain secara beradab, baik, dan sopan (Samani, 2011).

Kesepuluh, peserta didik harus terlebih dahulu memberi salam kepada gurunya, mengurangi percakapan di hadapan guru, jangan mengatakan kepada guru bahwa orang lain mengatakan hal yang berbeda dari yang beliau katakan, dan jangan pula bertanya kepada guru siapa teman duduknya.

Kesebelas, hendaknya peserta didik tekun belajar, mengulangi pelajarannya diwaktu senja, dan menjelang subuh. Waktu antara isya dan makan sahur itu adalah waktu yang penuh berkat hal mengajarkan peserta didik agar menjadi pribadi disiplin. Dalam pendidikan moral, sikap disiplin tidak secara otomatis tidak ada pada diri seseorang sejak dilahirkan, melainkan dibentuk oleh lingkungannya melalui pola asuh dan perlakuan orang tua, pendidik, dan orang disekitarnya (P Daeng Sari, 1996).

Keduabelas, peserta didik harus memiliki motivasi didalam dirinya untuk selalu belajar hingga akhir hayat, menghargai setiap cabang ilmu, dan memiliki pikiran bahwa setiap ilmu memiliki faedahnya ('Athiyah Al-Abrasyi, 1996). Seorang pendidik harus 
memberika perhatian pada maksimal kepada peserta didik khususnya bagi peserta didik yang kurang memiliki motivasi didalam dirinya dengan cara melihat dengan jeli kondisi peserta didik tersebut.

\section{Metode Pendidikan Moral}

Adapun proses penanaman serta pembinaan pendidikan moral berdasarkan konsep pemikiran 'Athiyah Al -Abrasyi adalah pembentukan akhlak dan budi pekerti yang sanggup menghasilkan orang-orang yang bermoral, laki-laki maupun wanita, jiwa yang bersih, kemauan yang keras, cita-cita yang benar dan akhlak yang tinggi, tau arti kewajiban dan pelaksanaannya, menghormati hak-hak manusia, tahu membedakan yang baik dan buruk, memilih suatu fadhilah karena cinta pada fadhilah, menghindari suatu perbuatan yang tercela karena ia tercela, dan mengingat Tuhan dalam setiap pekerjaan yang mereka lakukan (Al-Abrasyi, 1970).

'Athiyah Al-Abrasyi menawarkan pemikirannya tentang metode dalam pendidikan moral yang dapat di aplikasikan di dunia pendidikan di Indonesia. Beberapa metode atau cara yang ditawarkan yaitu:

\section{Pendidikan Secara Langsung}

Kurikulum yang digunakan oleh pendidikan di Indonesia pada saat sekarang ini tidak terlepas dari metode pendidikan secara langsung. Dalam proses pendidikan secara langsung peserta didik mengembangkan pengetahuan, kemampuan berfikir dan keterampilan psikmotorik melalui interaksi langsung dengan sumber pembelajaran (Pembelajaran Langsung Dan Tidak Langsung, n.d.). Dalam pendidikan moral, pendidikan secara langsung yang ditawarkan oleh 'Athiyah Al-Abrasyi dapat dilakukan dengan cara mempergunakan petunjuk, tuntunan, nasehat, menyebutkan manfaat, dan bahayabahayanya sesuatu dimana peserta didik dijelaskan tentang hal yang bermanfaat maupun yang tidak bermanfaat, mendorong agar 


\section{el-Tarbawj Fikri Abdul Aziz}

memiliki kesadarn untuk beramal baik, memiliki budi pekerti yang tinggi, dan menghindari hal-hal yang tercela (Al-Abrasyi, 1970).

Adapun media yang digunakan dalam pembelajaran langsung yang ditawarkan oleh Athiyah adalah sajak-sajak, syair-syair, ceritacerita yang terdapat pada buku buku Islam dalam bidang sastera, sejarah penuh dengan kata-kata khitmat, wasiat-wasiat, petunjukpetunjuk berguna sehingga ritme yang didengarkan oleh seseorang akan menggugah dan memiliki kesan yang ditimbulkan dalam jiwa (Al-Abrasyi, 1970). Jika kita relevansikan dalam dunia pendidikan sekarang, ini pendidik atau seorang guru harus memiliki kemamampuan dalam memberikan metode kreatif dan inovatif seperti menggunakan kemampuan dalam bermain musik dengan mengiringi peserta didik dengan nyanyian seperti sholawatan, nyanyian islami, dan nyanyian yang didalamnya memiliki nilai-nilai moral, contohnya lagu Melly Guslow dengan judul Ibu. Dalam lagu itu membawa pesan bahwa seorang anak harus tau perjuangan seorang ibu dalam mendidik, mengasuh, dan membesarkan kita dari dalam kandungan hingga menjadi orang yang sukses dibidangnya.

\section{Pendidikan Akhlak Secara Tidak Langsung}

Pendidikan secara tidak langsung pada umumnya berpusat pada peserta didik dimana peran seorang guru bergeser dari ceramah menjadi fasilitator yang dapat mengelola lingkungan belajar dan menjadikan peserta didik selalu terlibat dalam setiap pembelajaran yang dilakukan (Hamruni, 2008). Dalam pendidikan moral, pendidikan secara tidak langsung yang ditawarkan oleh Athiyah Al Abrasyi adalah memberikan sugesti kepada anak dengan cara mendektekan sajak-sajak yang mengandung hikmat yang berisi tentang nasehat-nasehat dan berita-berita berharga yang teraplikasikan dalam kegiatan-kegiatan pembelajaran. Adapun pendidikan tidak langsung yang ditawarkan oleh 'Athiyah sejalan dengan metode pendidikan dalam pemikiran Al-Ghazali. 
Metode pendidikan moral dapat ditempuh dengan dua jalan yaitu dengan mengekang hawa nafsu (mujahaddah) dengan mengerjakan amal sholeh. Amal sholeh yang bisa dianjurkan pendidik kepada peserta didik adalah membiasakan kepada peserta didik untuk berpuasa. Melalui berpuasa secara tidak langsung peserta didik akan terkontrol, sehingga dapat melunakan dan membersihkan hati, menghindarkan diri dari pembicaraan yang tidak bermanfaat, serta membiasakan kepada peserta didik untuk berbicara seperlunya (Musyarofah, 2017).

\section{Pendidikan Keteladanan}

Dalam pendidikan keteladan 'Athiyah menawarkan agar setiap pendidik berhias dengan akhlak yang baik, mulia, dan menghindari setiap yang tercela. Dalam hal ini, peserta didik dapat mengambil manfaat dari kecenderungan dalam mengikuti, meniru ucapan, perbuatan, gerak gerik orang yang berhubungan erat dengan mereka (Al-Abrasyi, 1970).

Adapun pendidik yang menjadi teladan bagi peserta didik harus memiliki kreteria yaitu, memiliki kezuhudan, tidak mengutamakan materi, dan mengajar karena mencari keridhoan Allah semata, seorang guru harus bersih secara jasmani dan rohani sehingga terhindari dari dosa kecil maupun dosa besar, ikhlas dan pekerjaan, memiliki sifat pemaaf, memiliki sifat menjadi orang tua bagi peserta didik, memahami tabi'at atau dalam bahasa modern mengetahui psikologis seorang peserta didik, dan yang terpenting adalah menguasai mata pelajaran yang diajari termasuk dalam pendidikan moral (Al-Abrasyi, 1970).

Tujuan dalam mengarungi pendidikan Islam adalah Pendidikan moral, akhlak dan Pendidikan rohani. Para pendidik tidak hanya menyanpaikan ilmu pengetahuan semata, namun harus mengutamakan moral dan akhlaknya. Para pendidik menjadi tauladan bagi peserta didik dalam Pendidikan Islam. Akhlak menjadi 


\section{$e^{\text {I-Tarbawj Fikri Abdul Aziz }}$}

hal yang sangat diutamakan dala Pendidikan Islam sebagai tiangnya. Dan tujuan dalam hidup ini hakikatnya adalah terciptanya kesempurnaan akhlak (Al-Abrasyi, 1970).

\section{Konsep Materi Pendidikan Moral}

Dilihat dari pemikiran 'Athiyah tentang bagaimana menggambarkan suatu ilmu pengetahuan, Beliau merupakan penganut paham pragmatis teologis. Artinya suatu ilmu pengetahuan dari segi pemanfaatannya yang didasarkan pada tujuan keagamaan dimana tujuan keagamaan tersebut menekan pada aspek pembentukan moralitas individu pada masyarakat.

Adapun materi pendidikan moral menurut 'Athiyah Al-Abrasyi lebih menekankan pada pembiasaan terhadap aktifitas anaksejak waktu masih kecil. Misalnya membiasakan tidur tidak larut malam, membiasakan untuk anak selalu bergerak, membiasakan anak supaya jangan meludah ditempat-tempat umum, membiasakan untuk tidak membuang ingus atau berdiri membelakangi dimana ada orang lain, membiasakan untuk tidak ongkang kaki, menasehati agar anak tidak berbuat dusta dan tidak melakukan sumpah baik benar maupun salah, dan membiasakan untuk mentaati ibu bapak dan gurunya.

Selain dengan cara pembiasaan, pendidik juga dapat memberikan wasiat berupa materi tentang: (1) peninggalan yang terbaik adalah sopan santun (2) Teman yang sangat sejati adalah budi pekerti yang baik (3) pemimpin yang baik adalah ketika menyepakati suatu hal secara Bersama dan konsisten (4) dagang yang untung adalah ijtihad (5) yang sangat bermanfaat adalah akal (6) kebodohan merupakan bencana terbesar (7) pengagungan terhadap dirinya sendiri adalah teman yang tidak baik (Al-Abrasyi, 1970). 


\section{Kesimpulan}

Sebagai seorang tokoh besar dalam bidang pendidikan, 'Athiyah Al Abrasyi memberikan gagasan tentang permasalahan krisis moral yang ada di Indonesia saat ini. Beberapa dasar pendidikan pemikiran 'Athiyah Al-Abrasyi pada dasarnya membawa konsep tentang proses pembelajaran yang mengarahkan pada peserta didik yang belum dewasa. Dalam islam peserta didik adalah manusia yang memiliki fitrah yang membutuhkan pengajaran, pelatihan, dan bimbingan dari pendidik dengan tujuan untuk mengantarkan kepada pematangan diri sehingga fitrah yang dimiliki jika ditangani dengan baik maka peserta didik itu nantinya akan menjadi seorang yang memiliki moral yang berkualitas.

Adapun menurut 'Athiyah Al-Abrasyi menyebutkan bahwa ada beberapa dasar-dasar pokok pendidikan Islam, diantaranya yaitu: (1) Tidak ada pembatasan umur untuk mulai belajar; (2) Tidak ada batasan lamanya anak belajar di Sekolah; (3) Berbedanya cara yang digunakan dalam memberikan pelajaran; (4) Dua ilmu jangan dicampuradukan; (5) Menggunakan contoh-contoh yang dapat dicapai dengan panca indera untuk mendekatkan pengertian pada anak-anak; (6) Memperhatikan pembawaan anak dalam beberapa mata pelajaran sehingga mereka dengan mudah dapat mengerti; (7) Memulai dengan pelajaran bahasa arab kemudian pelajaran al-Qur'an; (8) Pengertian terhadap pembawaan insting anak-anak dalam pemilihan pekerjaan; (9) Permainan dan hiburan; (10) Mendidik perasaan.

\section{Daftar Pustaka}

Al-Abrasyi, M. A. (1970). Dasar Pendidikan Islam (Terjemahan). Bulan Bintang. 


\section{$e^{\text {I-Tarbawj Fikri Abdul Aziz }}$}

Anas Adi, I. (2018). Analisis Kritis Pemikiran Pendidikan Progresif Muhammad 'Athiyah Al-Abrasyi (Prespektif Filsafat Pendidikan Islam). Inspirasi, 1(3).

Arifin, Z. (2012). Pengembangan Manajemen Mutu Kurikulum Pendidikan Islam. Diva Press.

'Athiyah al-Abrasyi, M. (1975). At-tarbiyah al-Islamiyahwa Fafasifatuha. Isa al-Babi al-Halabi.

'Athiyah Al-Abrasyi, M. (1996). Beberapa Pemikiran Pendidikan Islam (Terjemahan). Titian Ilahi Press.

Djuwaeli, I. (1998). Pembaruan Kembali Pendidikan Islam. Karsa Utama Mandiri dan PB. Mathlo'ul Anwar.

Hamruni. (2008). Startegi dan Model-model Pembelajaran Aktif. Fakultas Tarbiyah UIN Sunan Kalijaga.

Langgulung, H. (1991). Kreatifitas dan Pendidikan Islam: Analisis Psikologi dan Falsafah. Pustaka Al-Husna.

Mustaqim. (2001). Psikologi Pendidikan. Pustaka Pelajar.

Musyarofah. (2017). Metode Pendidikan Akhlak Menurut imam Ghozali. UIN Maulana Malik Ibrahim.

P Daeng Sari, D. (1996). Metode Mengajar di Taman Kanak-Kanak. Departemen Pendidikan dan Kebudayaan.

Pembelajaran Langsung dan Tidak Langsung. (n.d.). Retrieved April 4 , 2019, from https://onopirododo.wordpress.com/2013/10/24/pembelajaranlangsung-dan-tidak-langsung/

Rasyidin, A. (2012). Falsafah pendidikan Islami: Membangun Kerangka Ontologi, Epistimologi, Aksiologi Praktik Pendidikan. Cipta Pustaka Media Perintis.

Samani, M. dan H. (2011). Konsep dan Pendidikan Karakter. Remaja Rosdakarya.

Sujarwo. (2010). Peran Guru Dalam Pendidikan Nilai Pada Anak. Dinamika Pendidikan, 2(1).

Syaodih, N. (2009). Metode Penelitian Pendidikan. Remaja Rosdakarya. 